\title{
Severe subcutaneous emphysema in a term neonate
}

\author{
Mahesh Masand, ${ }^{1}$ Catherine Hauptfleisch ${ }^{2}$
}

${ }^{1}$ Department of Paediatrics, Dr Gray's Hospital, Elgin, Morayshire, UK

${ }^{2}$ Department of Neonatology, Aberdeen Maternity Hospital, Aberdeen, Aberdeenshire, UK

\section{Correspondence to} Dr Mahesh Masand, mmasand@nhs.net

Accepted 22 August 2018

\section{DESCRIPTION}

The baby was born by elective caesarean section because of breech presentation, at $38+6$ weeks of gestation with an Apgar score of 9 at $1 \mathrm{~min}, 9$ at $5 \mathrm{~min}$ and a birth weight of $4.02 \mathrm{~kg}$. She was noted to be grunting at $20 \mathrm{~min}$ of age and had $\mathrm{O}_{2}$ saturations of $55 \%$ in air and therefore commenced on $\mathrm{O}_{2}$ by face mask initially, followed by continuous positive airway pressure (CPAP) at a pressure of $5 \mathrm{~cm}$ as $\mathrm{O}_{2}$ requirements remained high (up to 60\%). CPAP pressure did not need to be increased further as the $\mathrm{O}_{2}$ requirement came down to $40 \%$ and remained between $30 \%$ and $40 \%$ for the subsequent 24 hours. Initial capillary blood gas at 2 hours of age (on CPAP $5 \mathrm{~cm}, \mathrm{FiO}_{2}$ 0.35) showed: $\mathrm{pH} 7.28 ; \mathrm{pCO}_{2} 7.05 ; \mathrm{pO}_{2}$ 7.15 and $\mathrm{BE}-2$. Repeat capillary blood gas at 4 hours (on CPAP $5 \mathrm{~cm}, \mathrm{FiO}_{2} 0.35$ ) showed: $\mathrm{pH} 7.30 ; \mathrm{pCO}_{2}$ 6.95; $\mathrm{pO}_{2} 5.63 ; \mathrm{BE}-2$.

She developed a sudden-onset swelling of the anterior chest wall and neck at 24 hours of age with palpable crepitus and chest X-ray showed gross subcutaneous emphysema over the upper chest wall and neck, with bilateral pneumothoraces and air in the mediastinum (figure 1). The chest X-ray taken at 4 hours of age was unremarkable. The baby was then intubated, commenced on conventional ventilation, sedated and paralysed, and she settled quickly in $30 \%-40 \% \mathrm{O}_{2}$ on peak inspiratory

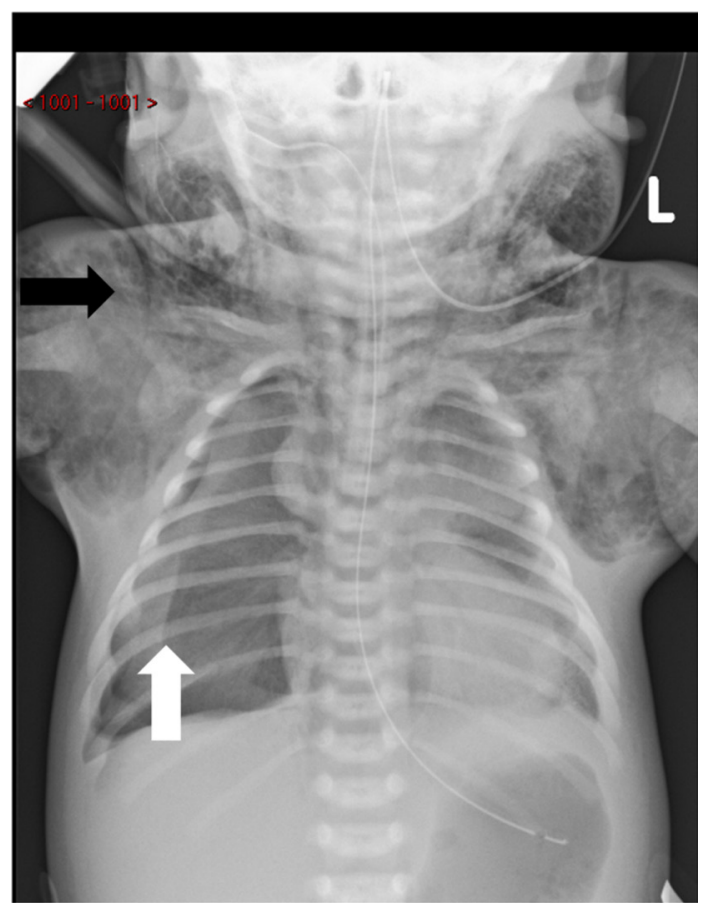

Figure 1 Chest X-ray showing mediastinal air, subcutaneous emphysema (black arrow) and pneumothorax (white arrow). pressure of $20-22 \mathrm{~cm}$. She also had a chest drain inserted on the right side for 24 hours and was extubated a further 24 hours later. She had a normal echocardiogram and barium study with no evidence of oesophageal perforation. A chest X-ray on day 10 of life showed almost complete resolution of subcutaneous air and the baby was discharged on day 12 of life.

Subcutaneous emphysema is a rare complication in newborns occurring secondary to pneumothorax and pneumomediastinum. The latter communicates with several anatomical structures outside the chest including the submandibular space, retropharyngeal space and the vascular sheath in the neck along which air can track under pressure. ${ }^{1}$ Conservative management normally suffices until the source of air leak closes, ${ }^{2}$ and the air in subcutaneous tissue gets absorbed spontaneously unless it is secondary to traumatic rupture of the trachea after a difficult intubation, ${ }^{3}$ when it can have high morbidity and mortality rates due to cardiac tamponade and will need aggressive treatment.

\section{Learning points}

- Subcutaneous emphysema fortunately is a very rare complication in newborn babies as compared to older children, even though air leak syndromes like pneumothoraces and pneumomediastinum are fairly common.

- Any type of mechanical ventilation including continuous positive airway pressure and intermittent positive pressure ventilation during resuscitation can lead to this serious complication and conservative treatment normally suffices until the air leak closes.

- Close monitoring is needed in all babies in case the air leak is secondary to tracheal rupture due to a difficult intubation; then it carries high morbidity and mortality due to cardiac tamponade which needs aggressive treatment.

Contributors MM was involved in planning, reporting, conception and designing of the report and $\mathrm{CH}$ was involved in management and data analysis.

Funding The authors have not declared a specific grant for this research from any funding agency in the public, commercial or not-for-profit sectors.

Competing interests None declared.

Patient consent Obtained.

Provenance and peer review Not commissioned; externally peer reviewed.

\section{REFERENCES}

1 Maunder RJ, Pierson DJ, Hudson LD. Subcutaneous and mediastinal emphysema. Pathophysiology, diagnosis, and management. Arch Intern Med 1984;144:1447-53. 
2 Corsini L, Dani C. Pneumomediastinum in term and la te pretem newborns: what is the proper clinical approach? The Journal of Maternal- Fetal \& Neonatal Medicine 2015;11:1332-5
3 Goudy SL, Miller FB, Bumpous JM. Neck crepitance: evaluation and management of suspected upper aerodigestive tract injury. Laryngoscope 2002;112:791-5

Copyright 2018 BMJ Publishing Group. All rights reserved. For permission to reuse any of this content visit http://group.bmj.com/group/rights-licensing/permissions.

BMJ Case Report Fellows may re-use this article for personal use and teaching without any further permission.

Become a Fellow of BMJ Case Reports today and you can:

- Submit as many cases as you like

Enjoy fast sympathetic peer review and rapid publication of accepted articles

- Access all the published articles

Re-use any of the published material for personal use and teaching without further permission

For information on Institutional Fellowships contact consortiasales@bmjgroup.com

Visit casereports.bmj.com for more articles like this and to become a Fellow 